\title{
Visitors to Protected Areas in China
}

Ralf Buckley [corresponding author] International Chair in Ecotourism Research, Griffith University, Gold Coast 4222, Australia Telephone: +61.7.55528675, Email: r.buckley@griffith.edu.au, ralf.c.buckley@gmail.com

Linsheng Zhong

Institute of Geographic Sciences and Natural Resources Research, Chinese Academy of Sciences, Beijing 100101, China. Email zhlsheng@263.net

Xiangyuan Ma

Institute of Geographic Sciences and Natural Resources Research, Chinese Academy of Sciences, Beijing 100101, China. Email maxiangyuan@foxmail.com 


\title{
Visitors to Protected Areas in China
}

\begin{abstract}
Conservation managers worldwide need social science information on visitors to protected areas, as well as natural science information on species and ecosystems. Visitor attitudes and behaviours differ considerably between countries and cultures, and these differences influence environmental impacts and management effectiveness. We present the first largescale multi-site study of motivations, activities, satisfaction and intentions for Chinese visitors to highly biodiverse, heavily-visited Chinese protected areas. At national scale, Chinese cultural attitudes to nature, animal welfare, and threatened species differ substantially from those in Western nations. Our results indicate that these differences are less marked for park visitors than for the general public. The main goal of Chinese park visitors is unstressed appreciation of nature in unpolluted environments, and they also enjoy adventure and cultural experiences. Differences appear only at finer scale, such as wildlife interactions and birdwatching expectations. Since $15 \%$ of Chinese park visitors plan their next park visit internationally, these results are also relevant for conservation in all countries that receive Chinese tourists. We suggest that Chinese park visitors might be able to catalyse broader Chinese cultural change in attitudes towards use of threatened species.
\end{abstract}

KEYWORDS: nature, reserve, management, recreation, attitudes, behaviour

\section{INTRODUCTION}

Conservation of biological diversity is both increasingly important and increasingly difficult (Barnosky et al. 2012; Hoffmann et al. 2015; Pimm et al. 2014; Saterberg et al. 2013). Human populations and impacts continue to increase; wildlife populations continue to decrease (Xie et al. 2015); and unmodified natural environments become increasingly rare and isolated (Buckley, Zhou and Zhong 2016). Conservation relies heavily on protected areas (Hoffman et al. 2015; Le Saout et al. 2014; Oldekop et al. 2015). These rely increasingly on political and economic support from tourism and recreation, especially visitors to protected areas (Buckley et al. 2012; Buckley, Morrison and Castley 2016; Palomo et al. 2014; Naidoo et al. 2016). Conservation pays a price for this support through the increased ecological impacts of more numerous and more demanding visitors to protected areas (Balmford et al. 2009; Buckley 2009). The intensity of impacts from individual visitors may differ by three orders of magnitude, depending on their activities, attitudes and behaviours (Buckley 2011). The motivations, activities, satisfaction and intentions of visitors to protected areas have thus become increasingly critical in conservation management worldwide.

In some continents, the psychology and behaviours of park visitors have been analysed extensively, and are incorporated routinely into operational planning, management and budgeting by protected area management agencies (Leung et al. 2016). Park visitors behave differently, however, in different countries, cultures, and circumstances (Conway 2013; Leung et al. 2016; Pearce 2014; Tucker and Carnegie 2014; Weiler et al. 2016). Conservation agencies in each country, and indeed at individual protected areas, therefore need information on visitors to their specific reserves. Currently, few parks agencies analyse the psychological factors driving visitors' decisions to visit a particular park, and their behaviour once they get there. 
Here, therefore, we address these questions for highly biodiverse and heavily visited protected areas in China. China has a large area, a very large population, and high biodiversity (Ding et al. 2012; Li et al. 2015; Liu et al. 2015; Luo et al. 2015; Wu et al. 2011; Zhang, Luo et al. 2016; Zhang, Slik \& Ma 2016; Zhao et al. 2016). It has a high degree of land conversion to primary production outside protected areas; numerous parks and nature reserves with high biodiversity and high visitation rates (Cao et al. 2015; Guo et al. 2015; Ren et al. 2015; Wu et al. 2011; Xie et al. 2015; Xu et al. 2014; Yang 2012; Zhong et al. 2015); and considerable anthropogenic modification to most of its existing protected areas (Buckley et al. 2016).

Management of China's many categories of protected areas (Ren et al. 2015; Ministry of Environmental Protection 1993; Zhong et al. 2015; Buckley et al. 2016) for the effective conservation of its threatened species and biological diversity despite high visitation, is thus of global conservation significance. The biodiversity and pristineness of these protected areas have been documented in some detail, but their many millions of visitors, an essential component in practical conservation, have remained largely unstudied except in localised cases. Here we examine visitor characteristics, using standardised approaches, for a national set of protected areas.

We focus particularly on potential differences between the attitudes and behaviours of Chinese park visitors, and those of their Western counterparts, which have been studied more extensively and form the basis for much of the international English-language park management literature (Lockwood et al., 2011; Leung et al., 2016). Chinese cultural attitudes towards nature have often been described as different from those in Western nations, with: less emphasis on the value of wilderness; greater emphasis on human health benefits of nature experiences and exposure; greater readiness to exploit threatened species, e.g. through consumption of traditional medicinal mixtures containing rare-species parts or extracts; and greater acceptance of very high visitation rates and large-scale infrastructure within protected areas (Foggin 2014; Wang and Buckley 2010; Wang et al. 2012; Xie et al. 2014; Xu and Fox 2014; Xu, Sun, and Liu 2014; Zhang, Fyall, and Zheng 2015; Zhong and Wang 2011; Zhong et al. 2015; Zhou and Yu 2004).

Cultural differences between China and Western nations have also been shown more broadly for all types of outdoor park, nature, wildlife and adventure tourism (Bao et al.,2014; Buckley 2016; Buckley et al. 2008; Buckley et al. 2014; Cong, Newsome et al. 2014; Du et al. 2016; He et al., 2008; Leung et al. 2014; Liu et al. 2012; Packer et al. 2014; Xu et al. 2014; Wang and Xu 2014; Wang et al. 2012; Xu and Fox 2014; Yang, 2012; Zhang et al. 2014 Zhong et al. 2015); and similarly, for outbound Chinese tourists travelling internationally (Jin and Sparks 2017; Prayag et al. 2015; Sun et al. 2015;Wu 2015; Wang et al. 2016).

Local-scale case studies of the motivations, awareness, experience and behaviour of protected area visitors in China have been reported at: Bitahai in Shangri-La, Yunnan (Xiao and Yang 2004); Baihuashan near Beijing (Li 2005); Taibai National Park in Shaanxi (Li 2005); Mt Yuntai in Henan (Chen and Qiao 2010); Mao'er Mountain in Guangxi (Liang and Wang 2013); Chengdu in Sichuan (Cong et al. 2014); and Jiuzhaigou in Sichuan (Du et al. 2016; Gu et al. 2013; Liu et al. 2012). There has apparently been no prior study, however, at national scale. Here we aim to provide such information, to assist the managers of China's protected areas in the conservation of its internationally significant biological diversity. 


\section{MATERIALS \& METHODS}

We examine the motivations, activities, satisfaction and intentions of Chinese domestic visitors to five iconic, heavily visited, high-tier conservation reserves in China. The parks studied are: Jiuzhaigou Nature Reserve in Sichuan province, Wudalianchi Geopark in Heilongjiang, Zhangjiajie National Forest Park in Hunan, Jianfengling National Forest Park in Hainan, and Nitoushan National Forest Park in Zhejiang. Annual visitation rates to these 5 parks, and the proportions of overseas visitors, are summarised in Table 1. By far the majority of visitors to each park are domestic Chinese tourists. At each of these parks, questionnaires were administered in person to Chinese visitors, at various dates from January to May inclusive. Respondents were selected randomly, except that no more than 5 members of any one organised package tour group were included. Each respondent completed the questionnaire independently. The overall structure of the questionnaires was first designed in English (Supplementary Table 1), to allow discussion between the authors, and the final version was constructed and administered in Chinese, by the Chinese authors.

Table 1. Park Visitation

\begin{tabular}{|l|r|r|r|}
\hline Park & $\begin{array}{r}\text { Total visitors } \\
\text { per year, 2015 }\end{array}$ & $\begin{array}{r}\text { Overseas visitors } \\
\text { per year, 2015 }\end{array}$ & $\begin{array}{r}\text { Overseas/total, } \\
\%\end{array}$ \\
\hline Jiuzhaigou & $5,096,000$ & 158,000 & 3.10 \\
\hline Zhangjiajie & $3,370,000$ & 212,000 & 6.29 \\
\hline Wudalianchi & $1,380,000$ & 95,000 & 6.88 \\
\hline Niutoushan & $1,201,000$ & 11,000 & 0.92 \\
\hline Jianfengling & 418,000 & 4,000 & 0.96 \\
\hline
\end{tabular}

We asked respondents to rate the importance of: 13 different motivations; 11 different activities, as measured by the relative amount of time spent engaged in each; their level of satisfaction, and degree to which expectations were met, for 13 different features and factors relating to the particular park concerned; and the likelihood that they would engage in any of six different potential activities in future park visits. All these questions used 5-point Likerttype scales. In conjunction with the last of these, we also asked: whether they planned to visit a park on their next holiday; if so, whether it would be in China or overseas; and whether they would prefer mountains, forests, grassland or desert, rural or cultural landscapes, freshwater lakes or rivers, or coastal and marine areas. We asked about trip logistics: whether respondents visited the park alone, or with various types of group; how many times each year they visit a park or reserve or similar area; what means of travel they used to reach this particular park or reserve; and how many days in total the trip would take. To allow us to test for demographic patterns and representativeness, we recorded: gender; geographic origins (province); age, in six brackets; education, in four brackets; occupation, in 22 categories; and monthly income, in six brackets.

We graphed the frequencies of response categories for motivations, activities, satisfaction and intentions respectively, using broken-stick displays. Using the raw data, we tested for any 
significant differences between similar categories or groups of categories, using Fisher's Exact Test. we also tested 3 (out of $~ 230$ ) possible a priori associations between each of these factors, and the various demographic parameters, to check for possible cultural differences between Chinese and Western park visitors. We tested whether interest in geological features is greater for older (more traditional) age brackets, and whether interest in bird watching is greater either for younger age brackets, or for higher income brackets.

\section{RESULTS}

Of the visitors approached, 85\% completed the survey in full. We received a total of 821 fully valid completed questionnaires: 254 at Jianfengling, 206 at Jiuzhaigou, 206 at Zhangjiajie, 117 at Wudalianchi, and 38 at Nitoushan. We first compared results between the 5 parks, but found no significant patterns, so we combined data from all 5 parks for subsequent analysis. These approaches generated a large data matrix ( $>45,000$ cells), with each cell containing categorical data (Supplementary Table 2). Results are summarised in Figure 1.

The principal motivations for Chinese visitors to Chinese protected areas are summarised in Figure 1a. The leading motivational factors, reported as important or very important by $60-80 \%$ of respondents, are generic characteristics of park visitors worldwide: scenery, nature, an iconic site, relaxation, and escape from city life. Social factors such as sharing with family and friends, and specific attributes such as history and adventure, were rated as important or very important for $45-60 \%$ of respondents. Convenience, catering and new companions were rated as important or very important by $<35 \%$. Fewer than $25 \%$ visited simply since the park was part of a package tour.

The activities and experiences in which Chinese park visitors engaged during their park visits are summarised in Figure 1b. Respondents were asked to rank importance in terms of the proportion of total time that they spent in different activities. Around $73 \%$ of respondents rated hiking on unformed trails, and taking photographs or videos, as important or very important. Around $45-55 \%$ of respondents said that walking on constructed tracks, learning about nature and geology, travelling between scenic lookouts by road or cableway, and learning about the geology, natural history and culture of the park were important or very important. Less than $30 \%$ of visitors reported that buying souvenirs or taking guided commercial tours were important or very important. Interests specifically in geology and birdwatching are not associated significantly with age or income bracket.

Visitor satisfaction is summarised in Figure 1c. Respondents were asked to report their satisfaction, and the degree to which their expectations were met, for each of the 13 factors considered. Overall, 85-90\% of respondents were satisfied or very satisfied with scenery and with air and water quality. Indeed, fewer than 5\% expressed themselves dissatisfied with air or water quality. For nature, wildlife and culture, $70-75 \%$ of tourists were satisfied or very satisfied. Around $50-60 \%$ were satisfied or very satisfied with the operational aspects of park management, including infrastructure, service, activities available, guiding and interpretation, responses to any complaints, and relations with local communities. Slightly lower proportions, around $43 \%$ of respondents, said they were satisfied or very satisfied with social opportunities and the commercial environment.

Around $64 \%$ of respondents said that they would visit another park or similar area on their next holiday. The remaining 36\% of respondents expected to visit a city, town, or theme park. 
Of the former, $14 \%$ expected to visit a national park in another country, with $86 \%$ planning to visit another park in China. Of the various landscapes available for future park visits, 31\% expressed preference for forests, $23 \%$ for coasts and oceans, $13 \%$ for freshwater, $13 \%$ for rural or cultural landscapes, $10 \%$ for mountains, and $10 \%$ for grasslands and deserts. Preferred activities for future park visits are summarised in Figure 1d. Around 70\% of respondents said that it was likely or very likely that they would take part in general sightseeing and local cultural experiences. A little over half, 50-60\%, expected to go hiking or take part in adventure activities such as rafting, mountain biking, surfing etc. Nature-based activities such as bird-watching and learning about plants and animals were mentioned by $\sim 45 \%$ of respondents. Differences in frequencies between these three groups of preferred activities are significant at $\mathrm{p}<0.05$.

Figure 1

a.
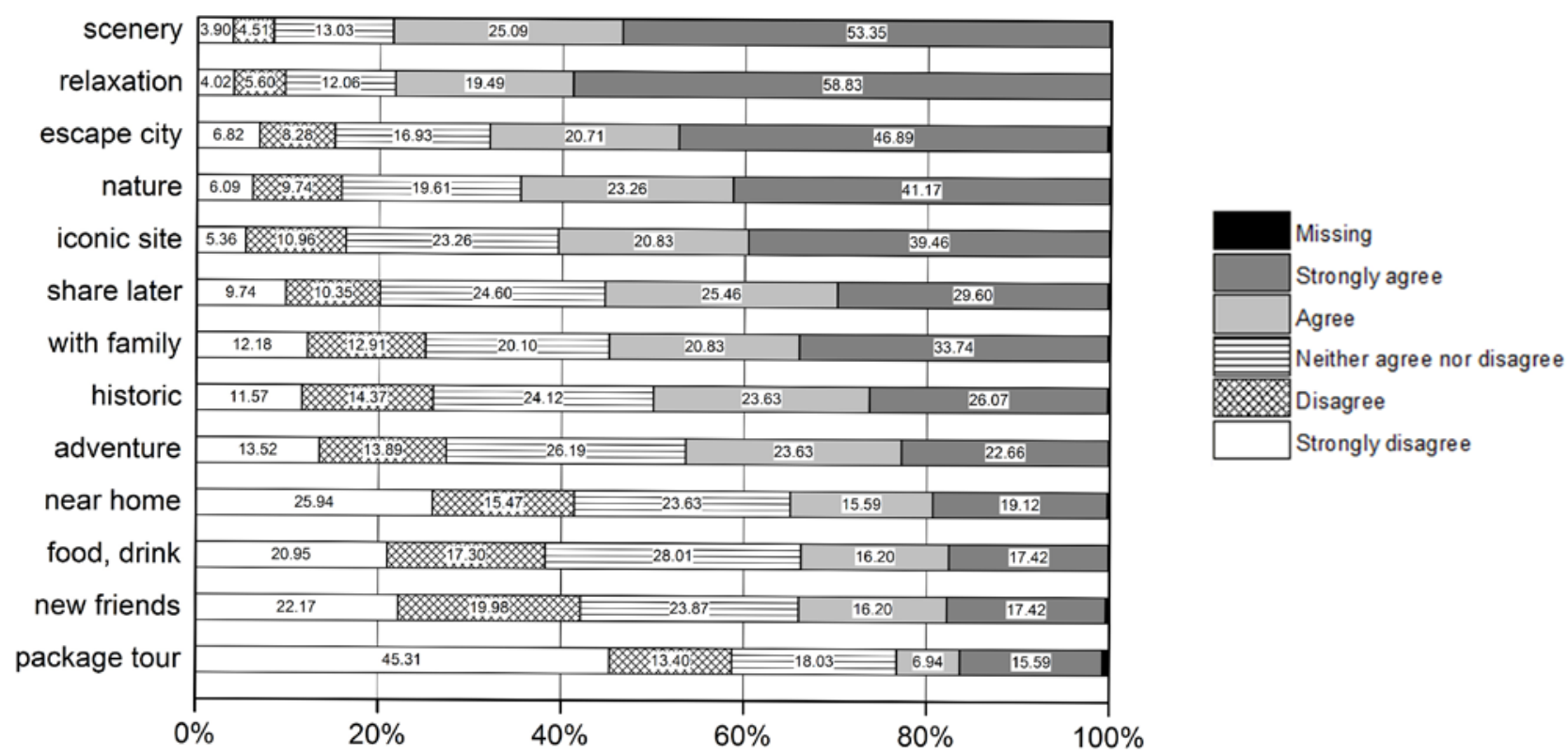

b.
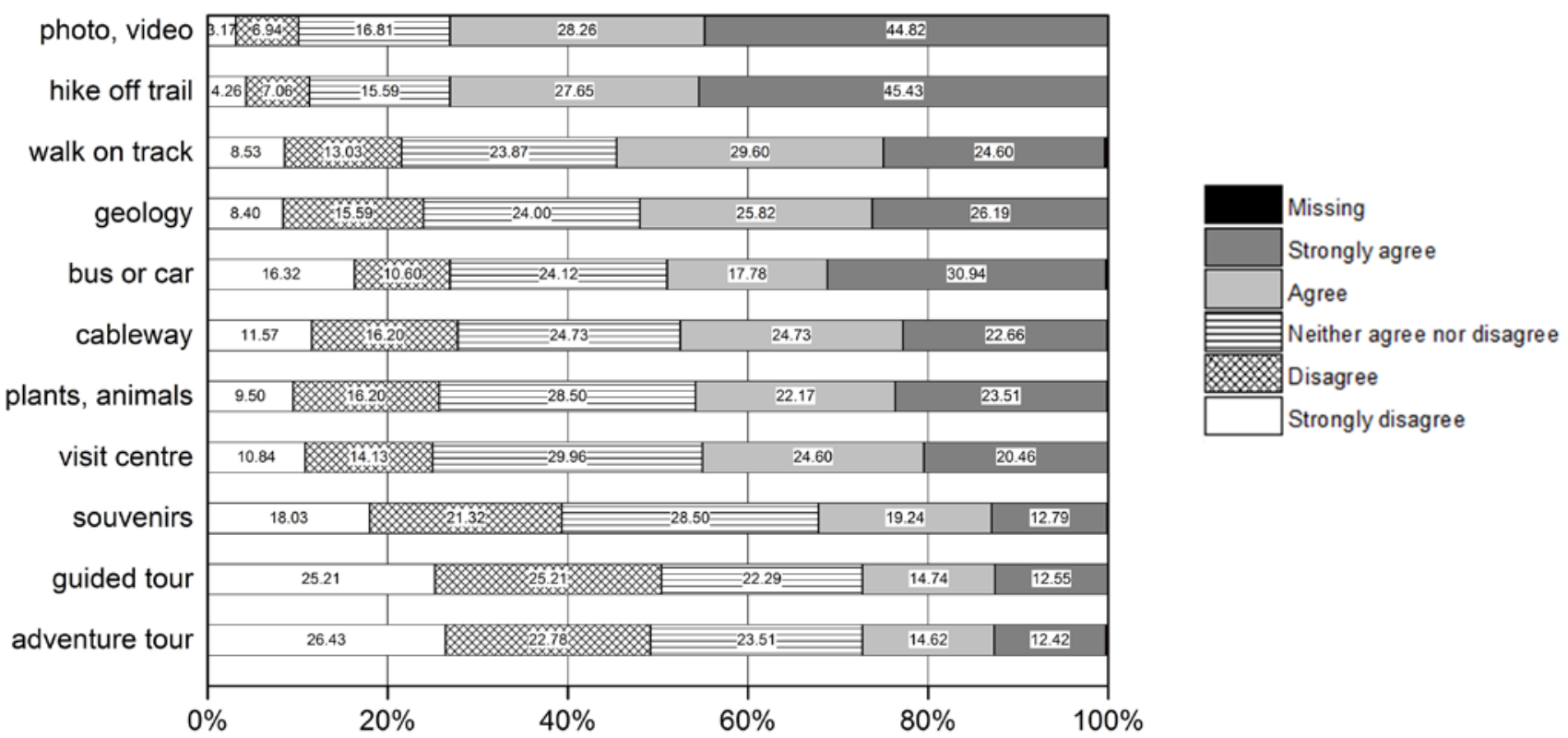
c.
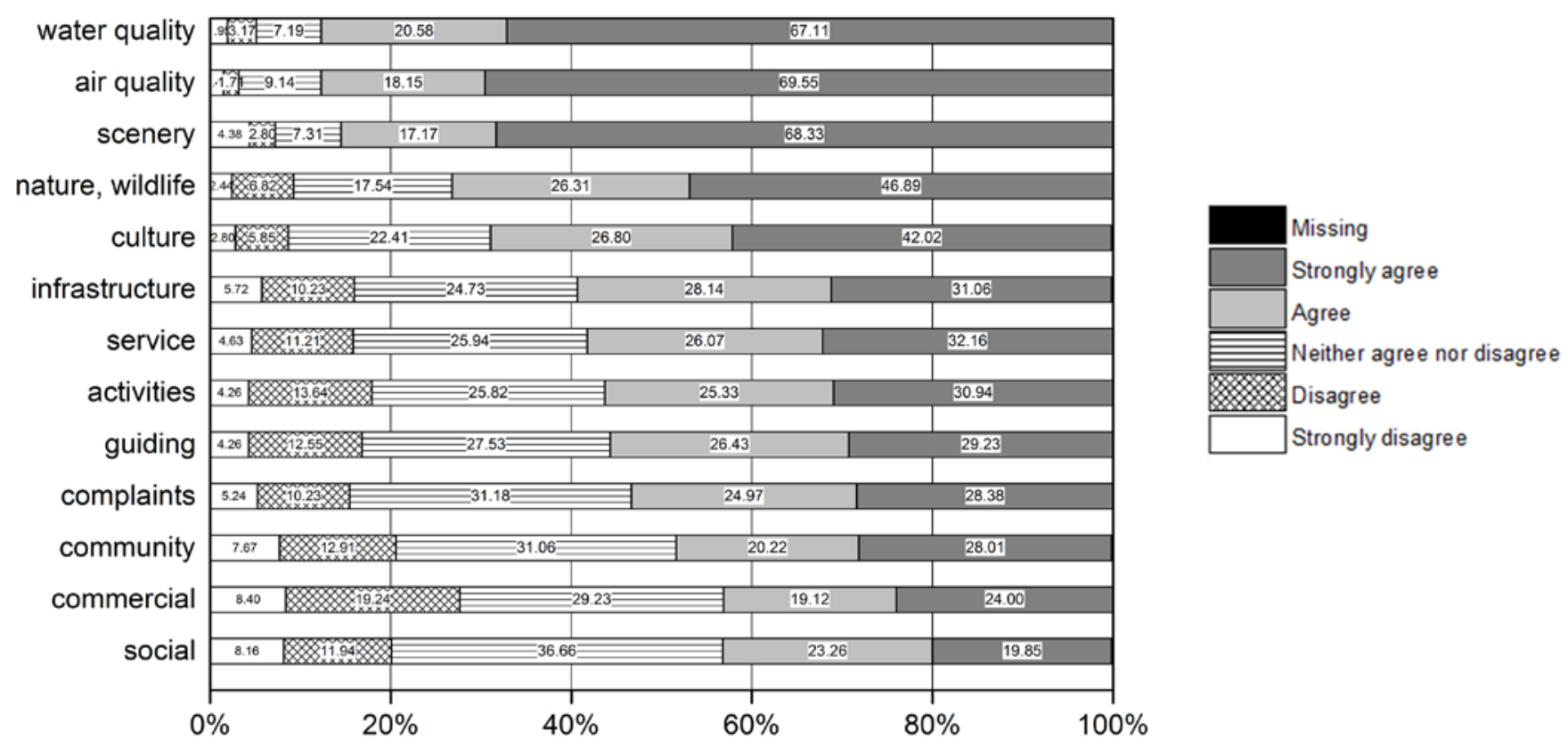

d.
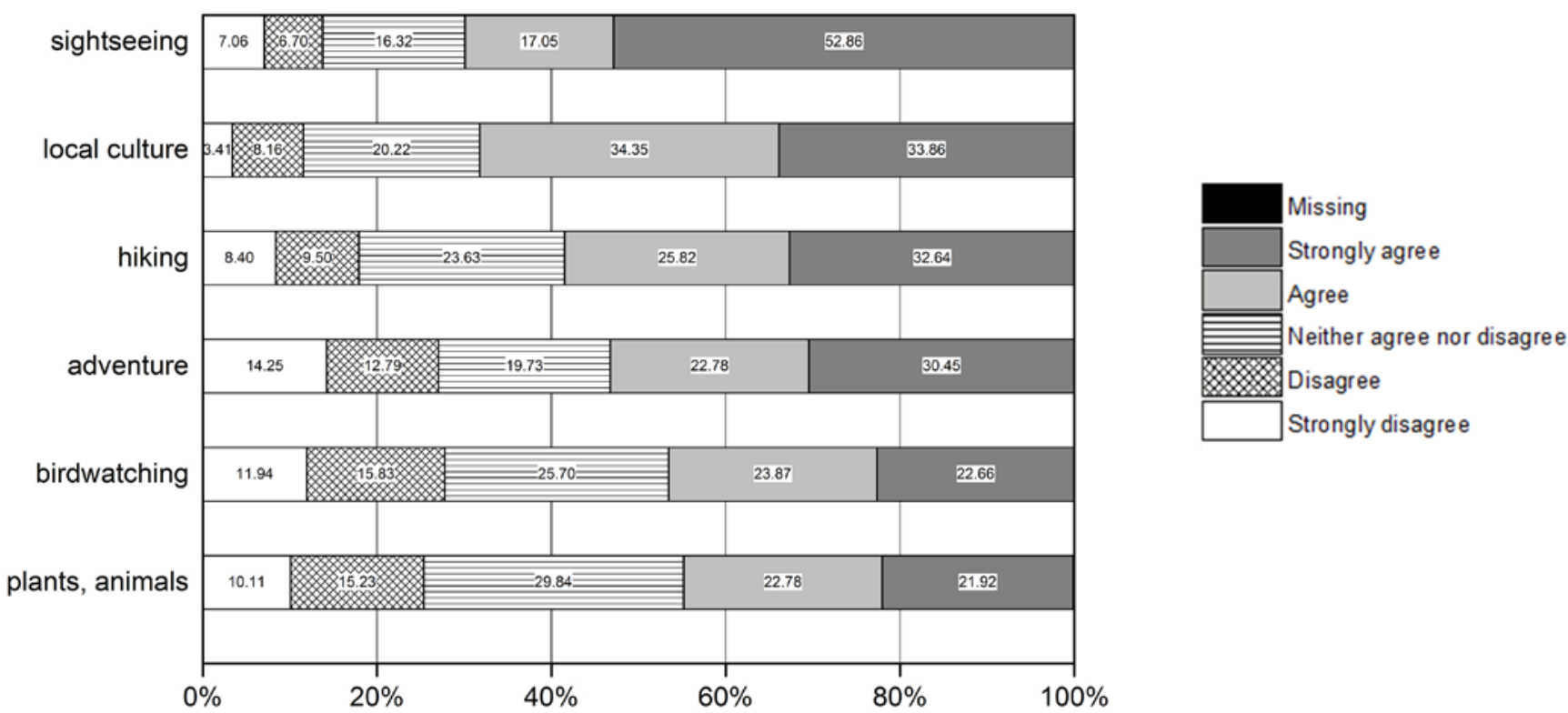

\section{DISCUSSION}

In summary, these results show that Chinese visitors to Chinese protected areas are closely comparable, in attitudes and activities, to Western visitors in Western protected areas, as reviewed by Leung et al. (2104). That is, the broad cultural differences between China and the West in attitudes to nature, wildlife and threatened species are not reflected amongst park visitors. In respect to their relationship with nature, Chinese visitors to Chinese parks are a self-selected subset of the Chinese population, with above-average interest and empathy for nature experiences. In this respect, they resemble Westerners who visit Western parks, more 
than Chinese citizens who do not visit Chinese parks. They are also relatively wealthy and well educated. Only $18 \%$ of our respondents were in a low-income bracket ( $<2000$ yuan p.a.), cf. 70\% nationally; and 69\% had completed college-level education, cf. 9\% nationally. Demographic statistics are summarised in Supplementary Table 3.

These results are unexpected. Previous studies have shown, for example, that Chinese park visitors have: different attitudes towards wildlife, than their Western counterparts ( $\mathrm{Li}$ et al. 2012; Cong, Wu et al. 2014); less interest in active pursuits in parks (Du et al. 2016); less interest in active involvement in outdoor recreation (Buckley et al. 2014); and more interest in purchasing souvenirs containing threatened species (Zhong et al. 2015). The Chinese concept of shengtai luyou includes greater emphasis on human health than the analogous Western concept of ecotourism (Zhong et al. 2008). The Chinese park management approach, shengtai anquan, explicitly incorporates human as well as conservation goals (Wang \& Buckley 2010). The results presented here, however, indicate that despite these differences, protected area management agencies in China can use the same toolkit of management measures as those in other countries. The same applies for protected areas in other countries that receive visitors from China (Buckley et al. 2014).

There are several areas of convergence between Chinese and Western park visitors. It has been argued, for example, that the concept of shengtai luyou indicates that Chinese park visitors show greater concern for human health, than those in the West (Buckley et al. 2008). More recent research in Western nations, however, has indeed shown strong links between nature exposure and human health, mental as well as physical (Capaldi, Dopko, and Zelenski 2014; Hartig et al. 2014; Korpela et al. 2014; Triguero-Mas et al. 2015).

There are case studies suggesting that visitors to protected areas in China expect and enjoy close encounters with semi-habituated wildlife ( $\mathrm{Li}$ et al. 2012), whereas those in Western nations want to see unmodified natural behaviours (Mossaz and Buckley 2016). At Zhalong in Heilongjing Province, for example, there is a wild migratory breeding population of the endangered red-crowned crane, Grus japonensis; but most park visitors see only habituated semi-captive resident individuals. Western park visitors, however, may not be so different. In the Gondwana Rainforests World Heritage Area (WHA) in Australia, there are wild populations of various parrot and bowerbird species, but most visitors see only habituated individuals that visit a licenced feeding area. Not all Western birdwatchers fit the stereotype of expensive cameras, binoculars, and lifetime lists (Steven, Morrison and Castley 2015).

As noted by Zhong et al. (2015), many protected areas in China have developed world leading approaches and technologies to manage high volume visitation with minimal environmental impact. These include: mass transit systems such as cableways and giant lifts, to replace winding mountain roads; fleets of electric minibuses to minimise noise and exhaust emissions; glass walkways and bridges; real-time visitor flow monitoring and control; centralised catering facilities; and fleets of mobile toilet buses that drive out of the park for pump-out. Though not as widespread, many of these infrastructure innovations do also exist in Western protected areas. There is a bus fleet at Denali National Park, USA, and walkways and a cableway in the Wet Tropics of Queensland WHA, Australia. The large recreational vehicles (RV's) used extensively by self-drive visitors to iconic parks in the USA, Canada and Australia have self-contained pump-out toilets. Visitor monitoring systems using mobile phone locations are now being deployed in many Western protected areas. 
There are still differences. Around 7\% of protected areas in China sell souvenirs made from threatened species (Zhong et al. 2015). This also occurs in other nations, from elephant hair bracelets in Africa to triton shells in the Pacific, but less so in North America. Iconic rocks in Chinese protected areas may be adorned with calligraphy. If modern, this would be treated as graffiti in Western nations. Elsewhere, however, ancient rock art is treated as valuable cultural heritage, by Western park visitors as well as indigenous residents. Some types of outdoor recreation available in Western protected areas are managed very differently in China, e.g. as shown by Buckley et al. (2014) for piaoliu ziyou, whitewater rafting.

Of all the cultural differences between China and Western nations, attitudes towards threatened species are perhaps the most critical for conservation of biological diversity. Despite some recent changes such as the 2017 ban on ivory trading (Chen 2016), China remains a major buyer of threatened species parts, both legal and illegal. In Western nations, a number of cultural attitudes and practices towards wildlife have proven at least partially labile through interpretation programs for park visitors (Leung et al. 2016). Perhaps Chinese visitors to Chinese parks could spearhead cultural change in China, leading to greater protection for threatened species worldwide. If so, this would be a major contribution to global conservation. As a next step in relevant research, therefore, we could use qualitative approaches to examine how strongly the attitudes and behaviours of Chinese park visitors are embedded in cultural antecedents. In addition, it may be possible to design experimental analyses to test the effectiveness of interventions aimed to modify cultural attitudes that affect threatened species.

\section{CONCLUSIONS}

The principal conclusions are as follows. Firstly Chinese park visitors have similar interests in nature to Western counterparts, and do not necessarily reflect attitudes reported for the broader Chinese population. Their main goal is unstressed appreciation of nature in unpolluted environments, and they also enjoy adventure and cultural experiences. Secondly, these similarities in interests allow convergence in protected area management practices, between Chinese and Western parks. In practice, there have been transfers of ideas and approaches in both directions. Thirdly, Chinese park visitors have different expectations for wildlife interactions and birdwatching from those reported elsewhere for Westerners (Buckley 2013; Steven et al. 2015). Finally, we suggest that educational materials provided specifically to Chinese domestic park visitors, might be able to influence their attitudes towards threatened plant and animal species, and that park visitors might be able to catalyse broader cultural change in Chinese attitudes to threatened species. If so, that would be of global conservation significance. We therefore propose that future research explore the attitudes of Chinese park visitors to human interactions with animals, and the use of threatened species.

\section{ACKNOWLEDGEMENTS}

This research was supported financially by the Chinese Academy of Sciences Visiting Professorships for Senior International Scientists (Project Number 2013T2Z0012), the National Natural Science Foundation of China (Project Number 41171435), and the Australia China Council (Project Number ACC201200021). 


\section{REFERENCES}

Balmford A, Beresford J, Green J, Naidoo R, Walpole M, Manica A. 2009. A global persective on trends in nature based tourism. PLoS Biology 7(6): e1000144.

Bao J, Chen G, Ma L. 2014. Tourism research in China: insights from insiders. Annals of Tourism Research 45: 167-181.

Barnosky AD, Hadly EA, Bascompte J, Berlow EL, Brown JH, Fortelius M, et al. 2012. Approaching a state shift in Earth's biosphere. Nature 486: 52-58.

Buckley R. 2009. Parks and tourism. PLoS Biology 7(6): e1000143.

Buckley R. 2011. Tourism and environment. Annual Review of Environment and Resources 36: 397-416.

Buckley R. 2013. To use tourism as a conservation tool, first study tourists. Animal Conservation 16: 259-260.

Buckley RC. 2016. Outdoor tourism in china: a foreigner's 30-year retrospective. Progress in Geography 35: 666-687.

Buckley RC, Castley JG, Pegas FV, Mossaz A, Steven R. 2012. A population accounting approach to assess tourism contributions to conservation of IUCN-Redlisted mammal species. PLoS ONE 7:e44134.

Buckley RC, Mcdonald K, Duan L, Sun L, Chen LX. 2014. Chinese model for mass adventure tourism. Tourism Management 44: 5-13.

Buckley RC, Morrison C, Castley JG. 2016. Net effects of ecotourism on threatened species survival. PLOS ONE 11:e0147988

Buckley, RC, Zhong LS, Cater C, Chen T. 2008. Shengtai lüyou: cross-cultural comparison in ecotourism. Annals of Tourism Research 35: 945-968.

Buckley RC, Zhou R, Zhong LS. 2016. How pristine are China's parks? Frontiers in Ecology \& Evolution 4: 136.

Cao M, Peng L, Liu S. 2015. Analysis of the network of protected areas in China based on a geographic perspective: current status, issues and integration. Sustainability 7: 15617-15631.

Capaldi CA, Dopko RL, Zelenski JM. 2014. The relationship between nature connectedness and happiness: a meta-analysis. Frontiers in Psychology 5: 976.

Chen J. 2016. On situation of and countermeasures for the smuggling of endangered wild animals in China under the backdrop of economic globalization. Journal of Customs and Trade 37(6): 92-99 (in Chinese). 
Chen N, Qiao GH. 2010. Comparative study on motivations of ecological tourists: case study of the geopark at Mount Yuntai Scenic Spot. Progress in Geography 27: 1005-1010 (in Chinese).

Cong L, Newsome D, Wu B, Morrison AM. 2014. Wildlife tourism in China: a review of the Chinese research literature. Current Issues in Tourism. Doi:10.1080/13683500.2014.948811.

Cong L, Wu B, Morrison AM, Shu H, Wang M. 2014. Analysis of wildlife tourism experiences with endangered species: an exploratory study of encounters with giant pandas in Chengdu, China. Tourism Management 40: 300-310.

Conway FJ. 2013. Local and public heritage at a World Heritage Site. Annals of Tourism Research 44: 143-155.

Ding J, Liu D, Li C, Jiang Z. 2012. Spatial variation in species richness of birds and mammals in mainland China. Shengtai Xuebao/Acta Ecologica Sinica 32: 343-350.

Du J, Buckley RC, Tang Y. 2016. Cultural differentiation in product choice by outdoor tourists. Tourism Recreation Research 41: 177-187.

Foggin JM. 2014. Managing shared natural heritages: towards more participatory models of protected area management in western China. Journal of International Wildlife Law \& Policy 17 (3): 130-151.

Gu Y, Du J, Tang Y, Qiao X, Bossard C, Deng G. 2013. Challenges for sustainable tourism at the Jiuzhaigou World Natural Heritage site in western China. Natural Resources Forum 37: 103-112.

Guo Z, Li Z, Cui GF. 2015. Effectiveness of national nature reserve network in representing natural vegetation in mainland China. Biodiversity and Conservation 24: 2735-2750.

Hartig T, Mitchell TR, de Vries S, Frumkin, H. 2014. Nature and health. Annual Review of Public Health 35: 207-228.

He G, Chen X, Liu W, Bearer S, Zhou S, Cheng LY, et al. 2008. Distribution of economic benefits from ecotourism: a case study of Wolong Nature Reserve for giant pandas in China. Environmental Management 42: 1017-1025.

Hoffmann M, Duckworth JW, Holmes K, Mallon DP, Rodrigues ASL, Stuart SN. 2015. The difference conservation makes to extinction risk of the world's ungulates. Conservation Biology 29: 1303-1313.

Jin X, Sparks B. 2017. Barriers to offering special interest tour products to the Chinese outbound group market. Tourism Management 59: 205-215.

Korpela K, Borodulin K, Neuvonen M, Paronen O, Tyrväinen L. 2014. Analyzing the mediators between nature-based outdoor recreation and emotional well-being. Journal of Environmental Psychology 37: 1-7. 
Le Saout S, Hoffmann M, Shi Y, Hughes A, Bernard C, Brooks TM, et al. 2014. Protected areas and effective biodiversity conservation. Science 342: 803-805.

Leung D, Li G, Fong LHN, Law R, Lo A. 2014. Current state of China tourism research. Current Issues in Tourism 17: 679-704.

Leung YF, Spenceley A, Hvenegaard G, Buckley RC, eds. 2016. Tourism and Visitor Management in Protected Areas. Gland: IUCN.

Li J. 2005. Chinese ecotourists' characteristics and motivational factors, using Shaanxi Taibai National Park as an example. Economic Geography 25: 720-723, 727 (in Chinese).

Li J, Tao SL, Yang DM, He L, Zeng L, Buckley RC. 2012. Psychological, physiological and behavioural responses of tourists to interactions with rhesus macaques at Zhangjiajie, China. Journal of Ecotourism 11: 202-206.

Li YQ 2005. A technique used in the identification and segmentation of ecotourists: a case study of Baihuashan Nature Reserve in Beijing. Acta Scientiarum Naturalium Universitatis Pekinensis 41: 906-917 (in Chinese).

Li X, Clinton N, Si Y, Liao J, Liang L, Gong P. 2015. Projected impacts of climate change on protected birds and nature reserves in China. Science Bulletin 60: 1644-53.

Liang J, Wang JY. 2013. Ecotourist motivation analysis based on a structural equation model: a case study in Mao'er Mountain National Nature Reserve in Guangxi. Journal of Northwest Forestry University 28: 227-233 (In Chinese).

Liu Q, Chen J, Corlett RT, Fan X, Yu D, Yang H, Gao J. (2015). Orchid conservation in the biodiversity hotspot of southwestern China. Conservation Biology, 29: 1563-1572.

Liu W, Vogt CA, Luo J, He G, Frank KA, Liu J. 2012. Drivers and socioeconomic impacts of tourism participation in protected areas. PloS ONE, 7 (4): e35420.

Lockwood M, Worboys G, Kothari A. 2012. Managing Protected Areas: a Global Guide. London: Earthscan.

Luo L, Wei S, Zhang W, Zhao M, Wu H. 2015. Amphibian biodiversity congruence and conservation priorities in China: integrating species richness, endemism, and threat patterns. Biological Conservation 191: 650-658.

Ministry of Environmental Protection \& General Administration of Quality Supervision, Inspection and Quarantine. (1993). Principles for Categories and Grades of Nature Reserve (GB/T 14529-93). Beijing: People’s Republic of China.

Mossaz A, Buckley RC. 2016. Decision making by specialist luxury travel agents. Tourism Management 55: 133-138.

Naidoo R, Fisher B, Manica A, Balmford A. 2016. Estimating economic losses to tourism in Africa from killing elephants. Nature Communications 7:13379. 
Oldekop JA, Holmes G, Harris WE, Evans KL. 2015. A global assessment of the social and conservation outcomes of protected areas. Conservation Biology 30: 133-141.

Packer J, Ballantyne R, Hughes, K. 2014. Chinese and Australian tourists' attitudes to nature, animals and environmental issues: implications for the design of nature-based tourism experiences. Tourism Management 44: 101-107.

Palomo I, Montes C, Martín-López B, González JA, García-Llorente M, Alcorlo P, Mora MRG. 2014. Incorporating the social-ecological approach in protected areas in the Anthropocene. BioScience, bit033.

Pearce DG. 2014. The internationalisation of tourism research. Journal of Travel Research 53: 267-280.

Pimm SL, Jenkins CN, Abell R, Brooks TM, Gittleman JL, Joppa LN, et al. 2014. The biodiversity of species and their rates of extinction, distribution and protection. Science 334: 1246752.

Prayag G, Cohen SA, Yan H. 2015. Potential Chinese travellers to western Europe: segmenting motivations and service expectations. Current Issues in Tourism 18: 725-743.

Ren GP, Young SS, Wang L, Wang W, Long YC, Wu RD, et al. 2015. Effectiveness of China's National Forest Protection Program and nature reserves. Conservation Biology 29: 1368-1377.

Saterberg T, Sellman S, Ebenman B. 2013. High frequency of functional extinctions in ecological networks. Nature 499: 468-470.

Steven R, Morrison C, Castley JG. 2015. Birdwatching and avitourism: a global review of research into its participant markets, distribution and impacts, highlighting future research priorities to inform sustainable avitourism management. Journal of Sustainable Tourism 23: 1257-1276.

Sun M, Ryan C, Pan S. 2015. Using Chinese travel blogs to examine perceived destination image: the case of New Zealand. Journal of Travel Research 54: 543-555.

Triguero-Mas M, Dadvand P, Cirach M, Martínez D, Medina A, Mompart A, et al. 2015. natural outdoor environments and mental and physical health: relationships and mechanisms. Environment International 77: 35-41.

Tucker H, Carnegie E. 2014. World Heritage and the contradictions of 'universal value'. Annals of Tourism Research 47: 63-76.

Wang C, Xu XP. 2014. The role of government and the private sector in China's tourism: the issue of sustainability. Tourism Management 45: 95-105.

Wang CH, Buckley RC. 2010. Shengtai anquan: managing tourism and environment in China’s Forest Parks. Ambio 39: 451-453. 
Wang G, Innes J, Wu S, Krzyzanowski J, Yin Y, Dai S, Zhang X, Liu S. 2012. National park development in China: conservation or commercialization? Ambio 41: 247-261.

Wang Y, Weaver DB, Kwek A. 2016. Beyond the mass tourism stereotype: power and empowerment in Chinese tour packages. Journal of Travel Research 55: 724-737.

Weiler B, Moyle BD, Wolf ID, de Bie K, Torland MA. 2016. Assessing the efficacy of communication interventions for shifting public perceptions of park benefits. Journal of Travel Research. doi:10.1177/0047287516646472.

Wu MY. 2015. Driving an unfamiliar vehicle in an unfamiliar country exploring Chinese recreational vehicle tourists' safety concerns and coping techniques in Australia. Journal of Travel Research 54: 801-813.

Wu R, Zhang S, Yu DW, Zhao P, Li X, Wang L. et al. 2011. Effectiveness of China's nature reserves in representing ecological diversity. Frontiers in Ecology \& Environment 9: 383-389.

Xiao ZX, Yang GH. 2004. A survey of the ecological awareness of domestic ecotourists: case study of Bitahai Ecological Scenic Spot, Shangri La. Tourism Tribune 19: 67-71 (in Chinese).

Xie GD, Cao SY, Yang QS, Xia L, Fan ZY, Gao Y, et al. 2015. Living Planet Report - China 2015. Beijing: World Wildlife Fund.

Xie Y, Gan X, Yang W. 2014. Strengthening the legal basis for designating and managing protected areas in China. Journal of International Wildlife Law \& Policy 17 (3): 115-129.

Xu F, Fox D. 2014. Modelling attitudes to nature, tourism and sustainable development in national parks: a survey of visitors in China and the UK. Tourism Management 45: 142-158.

Xu H, Cui Q, Sofield T, Li FMS. 2014. Attaining harmony: understanding the relationship between ecotourism and protected areas in China. Journal of Sustainable Tourism 8: 11311150.

Xu J, Sun G, Liu Y. 2014. Diversity and complexity in the forms and functions of protected areas in China. Journal of International Wildlife Law \& Policy 17 (3): 102-114.

Yang Y. 2012. Agglomeration density and tourism development in China: an empirical research based on dynamic panel data model. Tourism Management 33: 1347-1359.

Zhang C, Fyall A, Zheng Y. 2015. Heritage and tourism conflict within World Heritage sites in China: a longitudinal study. Current Issues in Tourism 18: 110-136.

Zhang L, Luo ZH, Mallon D, Li CW, Jiang ZG. 2016. Biodiversity conservation status in China's growing protected areas. Biological Conservation Doi:10.1016/J.Biocon.2016.05.005

Zhang MG, Slik JF, Ma KP. 2016. Priority areas for the conservation of perennial plants in China. Biological Conservation. doi:10.1016/j.biocon.2016.06.007

Zhao L, Li J, Liu H, Qin H. 2016. Distribution, congruence, and hotspots of higher plants in China. Scientific Reports 6: 19080. 
Zhong LS, Wu B, Morrison AM. 2015. Research on China's tourism: a 35-year review and authorship analysis. International Journal of Tourism Research 17: 25-34.

Zhong LS, Buckley RC, Wardle C, Wang LG. 2015. Environmental and visitor management in a thousand protected areas in China. Biological Conservation 181: 219-225.

Zhong LS, Wang J. 2011. Investigation and analysis of ecotourism development in protected areas of China. Acta Ecologica Sinica 31 (24): 7450-7457 (in Chinese).

Zhou N, Yu K. 2004. The urbanization of national parks and its countermeasures. Urban Planning Forum 1: 57-61 (in Chinese).

\section{FIGURE CAPTIONS}

Figure 1. (a) motivations, (b) activities, (c) satisfaction and (d) intentions of Chinese visitors to Chinese protected areas. Responses show the degree of agreement with statements in Supp. Table 1.

[NOTE: Figs 1a, 1b, 1c, 1d loaded as separate files to allow flexibility in layout at typesetting: either a 2 x 2 block or a 1 x 4 column].

\section{TABLE TITLES}

Table 1. Park visitation rates.

\section{SUPPLEMENTARY TABLES}

Supp. Table 1. Questionnaire (English version)

Supp. Table 2. Data matrix

Supp Table 3. Demographic statistics 